The International Journal of Human Resource Management, Volume 22, Issue 5, 2011, Pages 1146-1162

\title{
An examination of e-HRM as a means to increase the value of the HR
}

\section{function}

\section{Emma Parry}

Cranfield School of Management, Cranfield, United Kingdom

Dr Emma Parry

Senior Research Fellow

Cranfield School of Management

Cranfield

Beds MK43 0AL

United Kingdom

Tel: 01234751122

Email: emma.parry@cranfield.ac.uk 


\title{
An examination of e-HRM as a means to increase the value of the HR
}

\section{function}

\begin{abstract}
This article examines the potential use of e-HRM as a means to increase the value of the HR function, within the framework of the resource-based view. Past research has suggested that e-HRM may support the HR function in becoming more efficient, improving service delivery and adopting a greater role in delivering the firm's business strategy. The results from a large-scale survey across 12 countries showed that e-HRM may help HR to increase its value by becoming more strategic but found no evidence of cost savings due to reductions in HR headcount. This suggests that organisations are using e-HRM in order to redeploy HR practitioners from transactional work to more strategic and value added activities.
\end{abstract}

Keywords: e-HRM. HR function, resource-based view 


\section{Introduction}

The ways in which human resources are managed has changed dramatically in recent years. HR activities can now be delivered, not only by specialized HR professionals, but also increasingly by line managers, information technologies and through outsourcing (Tremblay, Patry and Lanoie, 2008; Ulrich, 1996). The focus of this study is one of these methods of delivery, information technology, or more specifically, e-HRM.

E-HRM has been defined as "a way of implementing HR strategies, policies and practices in organisations through a conscious and directed support of and/or with the full use of web-technology-based channels" (Ruel, Bondarouk and Looise, 2004, p.281) or more recently, and more broadly, as "the (planning, implementation, and) application of information systems for both networking and supporting actors in their shared performing of HR activities" (Strohmeier, 2007). E-HRM can be used for transactional activities (i.e. those that involve day-to-day transactions and record keeping); traditional HRM activities such as recruitment, selection, training, compensation and performance management; and transformational activities that add value to the organization (Thite and Kavanagh, 2008), and may be used to manage HR across the whole employee lifecycle. E-HRM varies not only in the functions for which it is used but also in the degree of sophistication which it involves (Martinsons, 1994). The development of web-based technology has allowed firms to provide services directly to employees and managers through the use of self-service systems. Over recent years, we have seen a shift in the delivery of transactional HRM from an approach which is "labour intensive" to one which is "technology-intensive" (Florowski and OlivasLujan, 2006) whereby a large proportion of transactional activities are now delivered using a wide variety of software rather than by HR administrators. 
There has been much discussion in the literature about the possible goals and outcomes of e-HRM (Ruta, 2005; Hawking, Stein and Foster, 2004; Ruel et al, 2004). EHRM has been suggested to have operational, relational and transformational impacts (Lepak and Snell, 1998). Similarly, Ruel et al (2004) suggested the four goals of cost-reduction, improving HR services, improving strategic orientation and global orientation. Much of this literature has focused on two main benefits of e-HRM for the HR function: the improvement of efficiency and reduction of costs associated with HRM (Buckley, Minette, Joy and Bartel, 2004) and the facilitation of a more strategic role for the HR function itself (Gardner, Lepak and Bartel, 2003; Snell, Stueber and Lepak, 2002). The common adoption of e-HRM (see for instance Cedar Crestone, 2007; CIPD, 2005) is presumably based upon the expectation of these positive consequences for e-HRM (Strohmeier, 2009). Therefore research is needed to establish the relationship between the use of e-HRM and factors such as efficiency and a strategic orientation for the HR function. Past research in the field of e-HRM has been criticised for a general lack of theory (Bondarouk and Ruel, 2009; Strohmeier, 2007). We will attempt to address this inadequacy by adopting a well-established theoretical framework in our analysis. This paper will therefore look at the potential consequences of e-HRM through the lens of the resource-based view (Barney 1991; Peteraf 1993) by examining the relationship between e-HRM use and a number of organizational characteristics.

Our paper will proceed with an analysis of the resource-based view and the value of the HR function as contributing to the achievement of competitive advantage. We will then consider the literature on the outcomes of e-HRM within this framework and develop a number of hypotheses based upon this literature, before presenting an empirical study, designed to test these hypotheses. 


\section{HRM and the resource-based view}

The resource-based view (RBV) defines the firm as a historically determined collection of resources (Lockett, Thompson and Morgenstern, 2009; Wernerfelt, 1984) that are valuable, rare, inimitable and imperfectly substitutable (Barney, 1991) and are the main source of an organisation's competitive advantage (Bowman and Ambrosini, 2000). A number of authors have applied the RBV to the field of strategic human resources (Wright, Dunford and Snell, 2001; Wright, McMahon and McWilliams,1994) through the suggestion that the knowledge, skills and activities of the workforce are core resources that contribute to the firm's competitive advantage .

The importance of human resources in the development of competitive advantage has received considerable attention in the RBV literature. As far back as 1959, Edith Penrose stated that value creation from the use of resources depend on the way that these resources are developed and deployed within the firm (Lockett, 2005). Therefore the knowledge, skills and actions of people is needed in order to create value from resources. In fact, it has been argued that competitive advantage only occurs when certain resource inputs are performing heterogeneously across different firms and that human resources are the only resource capable of doing this, therefore meaning that human resource are the sources of above normal returns, rather than physical or tradable assets (Bowman and Ambrosini, 2000; Barney, 1986). This assertion means that the role of the human resource function is all the more essential in order to maximise the value created through the effective development and deployment of human resources (Marler, 2009). Indeed, Lepak and Snell (1998) agreed that the value of an HR activity depends on its ability to help firms achieve a competitive advantage. Indeed the literature on strategic HRM has emphasized the fact that the HR function has the potential to produce human resources and organisational capabilities critical to achieving competitive advantage (Marler, 2009). In the sense that it can have an impact on 
the competitive advantage of the organisation, we can also treat the human resource function itself as a resource.

\section{The value of human resources}

The RBV stipulates that in order in order for resources (including HR) to create competitive advantage they must be valuable (Barney, 1991). Value for the HR function can be defined as "the strategic benefits achieved from a particular HR activity relative to the costs associated with its deployment" (Lepak and Snell, 1999, p222). Bowman and Ambrosini (2000) distinguished between "use value" (the perceived qualities of a good in relation to the customers' needs) and "exchange value" as the price or cost of the good. In the case of HRM, we can suggest that the HR function may contribute to a firm's competitive advantage by providing more effective management, development or deployment of the firm's human resources in a more efficient and effective manner.

So from an RBV perspective, HR activities can be equivalent across rival firms or one firm may be able to perform these activities in a superior way which confers competitive advantage to the firm. Where a firm has an HR-derived competitive advantage it is able to capture more value ('rents') than rival firms, and these rents are sustainable if these HR advantages are inimitable. Rents can accrue to the firm where HR activity either lowers relative costs, or helps the firm differentiate its products. Transactional HR activities could possibly be a source of rent-generating advantage where a firm was able to perform these activities at lower costs than rivals. Where HR activities enable the firm to develop superior talent, then these advantages have an indirect impact on the firm's resource base. In this sense these HR activities could be conceived of as resource-creating activities, rather than them being resources in their own right. This is rather a 'grey area' within the RBV, where some 
argue that resource-creating activities are 'dynamic capabilities', and thus do not directly create a stream of rents (e.g. Teece, Pisano and Shuen 1997; Eisenhardt and Martin 2000).

The assertion that the HR function can contribute to a firm's competitive advantage is in line with recent demands on the HR function whereby HR practitioners are commonly under pressure to be strategic and to act as a "business partner" as well as to be efficient and cost effective (Paauwe, 2004). The broad goals for HR can be broken down into three distinctive types: improving its transactional and traditional services for internal customers; addressing the strategic objectives of the business and being cost effective (Martin, Reddington and Alexander, 2008; Lepak and Snell, 1998). It can be proposed that, this suggestion is in line with the RBV as, if an HR function can improve its performance with regard to the first two of these goals it will increase its use value, whereas, the third of these three goals addresses the need for reduced costs. HR practitioners must therefore find a way of delivering HR practices in a way that is efficient and effective and can contribute to the achievement of the business strategy.

Bowman and Ambrosini (2000) have suggested that not all labour is capable of increasing competitive advantage. They divide labour into generic labour that conducts routine tasks that are codifiable and imitable, differential labour that is heterogenous across firms and is a source of uniqueness and potentially profit differentials and unproductive labour that destroys value by engaging in unnecessary tasks. It is differential labour that may lead to competitive advantage. If we apply this to the HR function, we can suggest that generic labour refers to routine and transactional HR activities, whereas differential labour refers to HR activities that add value to the firm and help the organization to deliver its business strategy. In line with the strategic HRM literature it could be said that, in order to increase their value, the HR function needs to conduct transactional activities (generic labour) 
as cheaply and efficiently as possible, remove unproductive labour and maximize the time and effort that they can spend on improving the service and support that they provide to the organization in delivering the business objectives.

\section{The role of e-HRM}

Past research has suggested that e-HRM can increase the efficiency of HR activities, improve HR service delivery and transform the role of the HR function into one that is more strategic (Martin, Reddington and Alexander, 2008, Ruel, Bondarouk and Looise, 2004; Hendrickson, 2003). If this is the case then the use of e-HRM may allow the HR function to increase its value and contribute to the competitive advantage of the firm, as discussed above. The more extensive deployment of technology and systems in the HR domain could be an additional source of rents. However, we might expect that technological and system assets would have lower barriers to imitability (Rumelt 1982) than, say, know-how advantages embedded in socially complex routines (Dierickx and Cool 1989). Although, it is safer to assume that even where a firm has deployed e-HRM technologies they may derive sustained advantages from the interactions between these, possibly imitable resources, and other more complex, path dependent resources. The purpose of this paper is to test the proposition that e-HRM can increase its value through the more efficient management of generic labour and effective support of differential labour (Bowman and Ambrosini, 2000). We will examine the past literature on e-HRM in order to discuss this proposition and to form hypotheses that we will then test empirically.

\section{Efficient management of generic labour}

There is a wide body of literature supporting the suggestion that e-HRM can improve the efficiency of HR activities by reducing costs and increasing the speed of processes. For 
instance, both Lepak and Snell (1998) and Hendrickson (2003) suggested that the use of eHRM can streamline transactional HR processes and increase efficiency. Ruel et al (2004) found evidence that one of the main goals of e-HRM was to produce efficiency gains or cost reductions by reducing headcount and removing administration. A number of authors have supported this assertion (Martin et al, 2008; Lengnick-Hall and Moritz, 2003; Enshur, Nielson and Grant-Vallone, 2002; Snell, Stueber and Lepak, 2002). The use of e-HRM as a more efficient way of performing administrative HRM tasks may lead to a need for lower numbers of HR staff as the technology can perform simple tasks quickly and accurately. Organizations may therefore use e-HRM as an alternative to having the HR capacity to perform administrative or transactional tasks manually. We may therefore expect HR functions to use e-HRM as a means of delivering these tasks more efficiency using less people. In particular, firms may use sophisticated e-HRM systems that offer manager and employee self-service in order to further reduce the need for large numbers of HR staff to be performing simple administrative tasks. We may therefore suggest that the use of e-HRM to perform routine tasks may replace the need for large numbers of HR staff, therefore producing a rent-generating advantage. Our first hypothesis will therefore examine the relationship between the ratio of HR staff to employees and the use of e-HRM.

Hypothesis 1: Organizations with that use e-HRM will have a lower ratio of HR staff to total employees.

\section{Support of differential labour}

The literature has suggested two main outcomes of e-HRM that may be described as promoting differential labour activities within the HR function. Firstly, the use of e-HRM has been linked with a transformation of the HR function into one that is more strategic or that spends more time on delivering the business strategy rather than on transactional HR 
activities (Ruel et al, 2004; Hendrickson, 2003; Lepak and Snell, 1998). Marler (2009) also suggested that an important goal for e-HRM is to support the strategic orientation of the HR function. A number of authors have proposed that e-HRM may support a change in focus for the HR function from administrative tasks to HR activities that have strategic relevance, are central to organisational performance and require a deep understanding of the organisation itself (Ruel et al, 2004; Shrivastiva and Shaw, 2004; Lawler and Mohrman, 2003). This suggestion has been much debated in the literature with some authors suggesting that e-HRM has not actually realised its potential for transforming the HR function into one that is more strategic (Burbach and Dundon, 2005; Gardner, Lepak and Bartol, 2005; Tansley, Newell and Williams, 2001). A more strategic HR function may be more effective at developing resources and will therefore generate higher rents (or value). We will therefore test the assumption that, in organisations that use e-HRM, the HR function will be more strategic. Hypothesis 2: HR functions in organizations which use e-HRM will play a strategic role in the organization.

Past literature has therefore hypothesized that the removal of the need for the HR function to perform transactional HR tasks means that they can focus on more strategic and value added activities (Strohmeier, 2007; Ruta, 2004; Lepak and Snell, 1998). However, this change in the role of the HR function requires a more developed level of expertise in the HR function than needed to perform transactional tasks. In line with the RBV, it can also be assumed that a more expert HR function is more likely to provide competitive advantage to the organisation. We may therefore find that HR experience is positively related to the use of e-HRM and therefore propose that:

Hypothesis 3: Organizations in which the senior HR manager has more experience will be more likely to use e-HRM. 
The literature has also suggested that e-HRM may allow the HR function to improve the level of service that it provides to the organisation (Ruel et al, 2004; Hendrickson, 2003) by enabling managers and employees to manage many aspects of human resources themselves. Lepak and Snell (1998) asserted that e-HRM can affect the "relational" aspects of HRM by providing managers and employees with remote access to HR information and increasing their ability to connect with other parts of the organisation so that they can perform HR activities themselves. Indeed, devolution of HRM activities to line managers is a commonly cited characteristic of strategic HRM (Larsen and Brewster, 2003; Whittaker and Marchington, 2003). We can therefore suggest that a positive relationship will be found between the use of e-HRM and the devolution of HR activities to line managers. In fact, sophisticated e-HRM systems often facilitate the performance of HR tasks by managers through manager self-service.

Hypothesis 4: Organizations that use e-HRM will be more likely to have a high devolution of HR tasks to line management.

Another innovation that has been associated with the efficiency of HR activities and also with a more strategic orientation of the HR function is HR outsourcing (HRO). HRO can be defined as "placing responsibility for various elements of the HR function with a thirdparty provider" (Cooke, Shen and McBride, 2005, p.415). Kanter (2003) has suggested that both HRO and e-HRM play an important role in the formation of the future HR architecture. In addition, both HRO and e-HRM have experienced similar patterns of growth (Tremblay, Patry and Lanoie, 2008) and have been suggested to have a similar impact on the efficiency and role of HR function. We might therefore suggest that these two initiatives will both be used by firms that wish to increase the contribution of the HR function to the competitive advantage of the organization. Indeed, the literature has suggested that activities are easier to 
outsource when they are electronic (Conklin, 2005) therefore we may expect a positive relationship between the two. Our next hypothesis is therefore:

Hypothesis 5: Organizations that use a high level of e-HRM will also use a high level of HRO.

The use of e-HRM may allow the HR function time to focus on providing an effective service to the organization. In addition, e-HRM can be used to provide accurate information on which the organization can make decisions about how best to manage their employees. In addition Hendrickson (2003) suggested that e-HRM leads to IT enabled processes such as computer-based training, that lead to new innovations in HR. E-HRM may therefore enable the HR function to improve the service that it offers to the organization (Ruel et al, 2004; Hendrickson, 2003). The need for the effective management of human resources and therefore a high level of service delivery from the HR department HRM might depend on how integral the firm's workforce is for its competitive advantage. Indeed, HRM has been suggested as being more important in knowledge intensive industries (Koch and McGrath, 1996). In organizations with a lot of highly qualified employees, it is essential that human resources are managed effectively. We therefore propose that organizations that have a high level of qualified employees will be more likely to have invested in e-HRM and to use this method.

Hypothesis 6: Organizations with a high level of qualified employees will be more likely to use e-HRM.

Past empirical evidence has found a positive relationship between e-HRM and organization size (Ball, 2001). We also suggest that as the introduction of e-HRM and in 
particular sophisticated self-service systems, requires an initial capital investment that may be relatively large, e-HRM will be more likely to be used in larger organizations. In addition, as larger organizations are more likely to achieve economies of scale, they may achieve greater efficiencies through using e-HRM. As the impact of size on the use of e-HRM may overshadow some of the other effects being investigated, size will be used as a control in our analysis. Another variable that has been used as a control in research on HRM is that of organization age (Delmotte and Sels, 2008), but past authors have not examined the influence of organization age on the use of e-HRM. We will therefore also use this as a control variable in our study.

The overall aim of this study therefore is to investigate the above hypotheses, in order to examine the consequences of e-HRM and to provide some insight into the use of e-HRM to improve the value of the HR function and therefore its contribution to the competitive advantage of the firm. This work will therefore build on the work of authors such as Wright et al (2001) that have examined HRM within the framework of the RBV, by focusing on one particular innovation in HRM - e-HRM.

\section{Methods}

Our investigation is based upon cross-sectional data derived from the 2003 Cranet survey of organizational human resource management policies and practices in 12 countries. Past research on e-HRM has focused on data from a single country, therefore it is important to establish whether the conclusions drawn from these studies (discussed above) are generalizable across more than one country. The countries used in this study were United Kingdom, USA, Australia, Canada, New Zealand, Germany, Switzerland, the Netherlands, Belgium, Norway, Finland and Austria. These countries were selected due to their participation in the Cranet network thereby meaning that data could easily be collected. In 
addition these countries have all seen a growth in the use of e-HRM over the past ten years. The use of a survey allowed us to examine relationships between the use of e-HRM and other characteristics of the HR function and wider organization.

The items within the survey are derived from a comprehensive review of the literature on HRM practices. The questionnaire was initially developed in 1989 based on the literature available at that time and on discussions within a network of academics with expertise in HRM. The survey has been repeated several times since 1989 and has been revised on each occasion, based upon up-dated literature reviews and upon discussions within the research team and with senior practitioners. In 2003, this research team consisted of academics from the 32 participating countries in order to ensure its relevance across cultures.

The questionnaire consists of a number of questions about HRM policies and practices and workforce characteristics at the organizational level. The questionnaire was developed in English and then translated into the language of each country by somebody with knowledge of HRM. In each case, the questionnaire was then translated back into English by a different individual with knowledge of HRM to ensure that the meaning of each question remained the same. Any differences found after the back translation were changed under discussion with the partner in each country, in order to ensure that the questions in each survey retained exactly the same meaning. Full details of this process can be found in Brewster, Hegewisch, Mayne and Tregaskis (1994).

The survey was targeted at the senior HR manager in each firm as they are presumed to be knowledgeable about the characteristics of their workforce and the existence of HRM practices within their organizations. This is in line with the "key informant methodology" described by Kumar, Stern and Anderson (1993). The adoption of key informant methodology allowed us to survey as many organizations as possible, therefore promoting generalisability, whereas the use of multiple informants would surely have resulted in a lower 
response rate. The questions asked were deliberately designed to rely on only factual information about the workforce and HRM as it operated within the organization, such as whether e-HRM was used for particular HR activities. Therefore respondents were not asked to make subjective judgements on behalf of the organization, such that a key informant approach would not be appropriate. As the respondent was the most senior HR manager in each firm it was presumed that they had the knowledge to answer these questions accurately. Respondents were advised to leave blank any questions for which they did not know the answer, in order to discourage "guessing".

The survey was mailed to HR managers in representative national samples of firms with more than 100 employees. The response rate for each country was between $20 \%$ and $35 \%$. Analyses of previous Cranet surveys suggest that the net sample is representative of the population in each country (see Brewster, Hegewisch, Mayne and Tregaskis, 1994). For the purpose of this analysis, only private sector firms were used in this analysis. Our sample consisted of 2,777 firms. Table 1 summarizes the country distribution of the sample.

Table 1: The number of firms from each country

\begin{tabular}{|l|c|c|}
\hline Country & $\mathrm{N}$ & $\%$ \\
\hline UK & 774 & 27.9 \\
\hline Germany & 264 & 9.5 \\
\hline The Netherlands & 174 & 6.3 \\
\hline Norway & 94 & 3.4 \\
\hline Switzerland & 221 & 8.0 \\
\hline Finland & 137 & 4.9 \\
\hline Austria & 198 & 7.1 \\
\hline Belgium & 201 & 7.2 \\
\hline Australia & 191 & 6.9 \\
\hline New Zealand & 183 & 6.6 \\
\hline USA & 133 & 4.8 \\
\hline Canada & 207 & 7.5 \\
\hline
\end{tabular}




\section{Measures}

Dependent measures:

Organisations can differ in their use of e-HRM in two ways. Firstly, firms may differ in their breadth of e-HRM as the number of HR activities that they use e-HRM for. Secondly, they can differ in the degree of sophistication of e-HRM from simple one-way communication systems to more complex systems involving manager and employee self-service. Therefore, we used two measures as dependent variables representing use of e-HRM.

E-HRM use: This measure asked respondents to indicate whether they used e-HRM for a particular HR activity by ticking yes or no. Therefore, for a list of nine HR activities payroll, benefits, time and attendance, recruitment, training, performance management, career/succession planning, work scheduling and health and safety - respondents were asked to indicate whether they used e-HRM. Scores on these nines variables were combined into an index for e-HRM use with 9 meaning high use of e-HRM (in that the organization used eHRM across a larger number of HR activities) and 0 meaning no use of e-HRM.

E-HRM sophistication: Respondents were also asked to indicate on a five-point scale how sophisticated their use of e-HRM. Objective anchors were provided for each point on the scale to promote factual and accurate answers. These were as follows by ticking one of the following options: $0=$ do not use e-HRM, $1=$ one way communication only; $2=$ one way but with some access for employees or managers; 3 = two-way with simple updates allowed by employees or managers; $4=$ two way with complex transactions; $5=$ a more complex system.

\section{Independent measures:}

Ratio of HR to employees: Operationalized as the percentage of employees that are in the HR department 
Strategic involvement of HR: Four items were combined to create an index pertaining to HR's involvement in strategy. Firstly, does the senior HR manager have a place on the Board of Directors or equivalent $(1=$ yes, $0=$ no). Secondly, does the firm have an HR strategy $(1=$ yes, $0=$ no) and finally, at what stage is HR involved in the development of the business strategy $(4=$ from the outset to $0=$ not involved $)$. Responses to these items were summed to create a scale from 0 (not strategic) to 6 (strategic).

HR manager experience: Respondents were asked how long they had worked in a specialist HR role (years).

Devolution to line management: Respondents were asked whether five activities - pay and benefits, industrial relations, recruitment and selection, workforce expansion/reduction and training and development - were performed by line management (1), line management with support from HR (2), HR with support from line management (3) or HR (4). Responses to these four questions were summed in order to create an index ranging from 5 to 20 .

HR Outsourcing: This measure was based on that used by Delmotte and Sels (2008). For a list of six HR activities - payroll, pensions, benefits, training and development delivery, outplacement and reduction and HR information systems - respondents were asked to indicate whether or not they used external providers (i.e. yes or no). These were chosen as they are those that are typically seen as consisting of administrative or transactional activity that is commonly outsourced. Scores on these six variables were combined into an index with 6 indicating high use of outsourcing and 0 no use of outsourcing.

Employee qualifications: The level of qualified employees was measured as the percentage of the workforce that were graduates.

\section{Controls:}

Two controls were included in the study : 
Organisation size: Operationalized as the $\log (10)$ of number of employees in the firm.

Organisation age: Operationalized as the $\log (10)$ of the number of years since the firm was founded.

\section{Results}

Table 2 shows a descriptive analysis of the data and the bivariate correlations between each variable (Pearson Correlation Coefficients).

Table 2 shows that there were a high number of significant correlations between variables. These correlations were relatively small and therefore not high enough to indicate multicollinearity. However, a high number of significant correlations between variables may be a sign of common method variance, meaning that there is spurious co-variance shared by variables due to a common method being used in collecting data. A principle components analysis with a varimax rotation was conducted in order to establish whether the variables loaded onto a single component (Harman's single-factor test). This test showed that in fact six components were needed in order to explain $66 \%$ of the variance, suggesting that common method variance was not a problem.

In order to investigate the impact of each predictor on the use and sophistication of e-HRM, two least squares regression analyses were conducted. In each case, the control variables of organization size and age were entered in the first step of the analysis. In the second step, the predictors of HR Outsourcing, Devolution to line management, Strategic involvement of HR, Ratio of HR to employees, HR manager experience, Employee qualifications and e-HRM use or sophistication were entered as predictors. In order to account for missing values and maximize the sample size for this analysis, pairwise deletion of variables was used. 
Table 2: Descriptives and bivariate correlations of predictors $(\mathrm{N}=2777)$

\begin{tabular}{|c|c|c|c|c|c|c|c|c|c|c|c|c|}
\hline & Mean & SD & 1 & 2 & 3 & 4 & 5 & 6 & 7 & 8 & 9 & 10 \\
\hline 1. e-HRM use & 4.84 & 1.90 & & $\begin{array}{l}.254 \\
* *\end{array}$ & $\begin{array}{l}.081 \\
* *\end{array}$ & $\begin{array}{c}.2 .49 \\
* *\end{array}$ & .022 & $\begin{array}{c}-.068 \\
* *\end{array}$ & $\begin{array}{c}.151 \\
* *\end{array}$ & & $\begin{array}{l}.109 \\
* *\end{array}$ & .026 \\
\hline 2. e-HRM sophis & 1.23 & 1.09 & $\begin{array}{l}.254 \\
* *\end{array}$ & & $\begin{array}{l}.184 \\
* *\end{array}$ & $\begin{array}{l}.303 \\
* *\end{array}$ & .025 & $\begin{array}{l}-.162 \\
* *\end{array}$ & $\begin{array}{l}.089 \\
* *\end{array}$ & & $.057^{*}$ & .023 \\
\hline 3.Outsourcing & 4.28 & 1.73 & $\begin{array}{c}.081 \\
* *\end{array}$ & $\begin{array}{c}.184 \\
* *\end{array}$ & & $\begin{array}{c}.162 \\
* *\end{array}$ & .000 & $\begin{array}{c}-.061 \\
* *\end{array}$ & $\begin{array}{l}.075 \\
* *\end{array}$ & & $\begin{array}{c}.084 \\
* *\end{array}$ & .029 \\
\hline 4. Size $(\log )$ & 2.68 & 0.60 & $\begin{array}{l}.249 \\
* *\end{array}$ & $\begin{array}{l}.303 \\
* *\end{array}$ & $\begin{array}{c}.162 \\
* *\end{array}$ & & $\begin{array}{c}.096 \\
* *\end{array}$ & $\begin{array}{c}-.152 \\
* *\end{array}$ & $\begin{array}{l}.102 \\
* *\end{array}$ & & $\begin{array}{l}.131 \\
* *\end{array}$ & -.020 \\
\hline 5. Age $(\log )$ & 1.61 & 0.45 & .022 & .025 & .000 & $\begin{array}{l}.096 \\
* *\end{array}$ & & $\begin{array}{c}-.057 \\
* *\end{array}$ & -.007 & & .029 & -.050 \\
\hline 6. Devolution & 12.19 & 3.22 & $\begin{array}{c}-.068 \\
* *\end{array}$ & $\begin{array}{c}-.162 \\
* *\end{array}$ & $\begin{array}{c}-.061 \\
* *\end{array}$ & $\begin{array}{c}-.152 \\
* *\end{array}$ & $\begin{array}{c}-.057 \\
* *\end{array}$ & & $\begin{array}{c}-.137 \\
* *\end{array}$ & & .007 & .030 \\
\hline 7. Strategic HR & 3.71 & 1.30 & $\begin{array}{l}.151 \\
* *\end{array}$ & $\begin{array}{l}.089 \\
* *\end{array}$ & $\begin{array}{l}.075 \\
* *\end{array}$ & $\begin{array}{l}.102 \\
* *\end{array}$ & -.007 & $\begin{array}{c}-.137 \\
* *\end{array}$ & & & $\begin{array}{l}.119 \\
* *\end{array}$ & .025 \\
\hline 8. HR Percentage & 1.68 & 4.60 & & & & & & & & & & \\
\hline 9.HR experience & 13.83 & 8.75 & $\begin{array}{c}.109 \\
* *\end{array}$ & $.057 *$ & $\begin{array}{c}.084 \\
* *\end{array}$ & $\begin{array}{c}.131 \\
* *\end{array}$ & .029 & .007 & $\begin{array}{l}.119 \\
* *\end{array}$ & & & -.040 \\
\hline 10. Human capital & 21.60 & 23.54 & .026 & .023 & .029 & -.020 & -.050 & .030 & .025 & & -.040 & \\
\hline
\end{tabular}


Table 3: Least squares regression of predictors onto e-HRM sophistication $(\mathrm{N}=2777)$

\begin{tabular}{|c|c|c|c|c|c|c|}
\hline & \multicolumn{3}{|c|}{1} & \multicolumn{3}{|c|}{2} \\
\hline Predictors & Beta & $\mathrm{t}$ & Sig & Beta & $\mathrm{t}$ & Sig \\
\hline Size (log) & .303 & 9.650 & .000 & .224 & 6.896 & .000 \\
\hline Age $(\log )$ & -.004 & -.133 & .894 & -.004 & -.140 & .889 \\
\hline Devolution & & & & -.107 & -3.438 & .001 \\
\hline Strategic involvement of HR & & & & .014 & .460 & .646 \\
\hline HR ratio & & & & .020 & .658 & .510 \\
\hline HR Experience & & & & -.002 & -.068 & .946 \\
\hline Human capital & & & & .022 & .731 & .465 \\
\hline Outsourcing & & & & .126 & 4.081 & .000 \\
\hline e-HRM use & & & & .179 & 5.655 & .000 \\
\hline Adjusted R Square (model) & \multicolumn{3}{|c|}{.90} & \multicolumn{3}{|c|}{.147} \\
\hline F change & \multicolumn{3}{|c|}{46.881} & \multicolumn{3}{|c|}{9.854} \\
\hline Significance of $\mathrm{F}$ change & \multicolumn{3}{|c|}{.000} & \multicolumn{3}{|c|}{.000} \\
\hline
\end{tabular}


Taking e-HRM sophistication as the criterion variable, both steps of the model produced a significant $\mathrm{F}$ change $(\mathrm{p}<0.01$ for both steps). These two steps produced an adjusted $\mathrm{R}$ square of 0.147 .

An examination of the results in table 3 indicates that, only one of the controls, organization size, has a significant positive impact on e-HRM sophistication suggesting that larger organizations are generally more sophisticated in their use of e-HRM. Of the predictor variables, devolution to line management had a significant negative effect on e-HRM sophistication indicating that firms in which the HR function retained responsibility for HR activities were more sophisticated in their use of e-HRM. Outsourcing and e-HRM use were significantly positively related to e-HRM sophistication suggesting that those firms that outsource more HR activities and that use e-HRM for a large number of HR activities are more sophisticated in their use of e-HRM. 
Table 4: Least squares regression of predictors onto e-HRM use $(\mathrm{N}=2777)$

\begin{tabular}{|c|c|c|c|c|c|c|}
\hline & \multicolumn{3}{|c|}{1} & \multicolumn{3}{|c|}{2} \\
\hline Predictors & Beta & $\mathrm{t}$ & Sig & Beta & $\mathrm{t}$ & Sig \\
\hline Size $(\log )$ & .249 & 7.786 & .000 & .173 & 5.151 & .000 \\
\hline Age $(\log )$ & -.002 & -.050 & .960 & .002 & .049 & .961 \\
\hline Devolution & & & & .003 & .106 & .916 \\
\hline Strategic involvement of HR & & & & .109 & 3.442 & .001 \\
\hline HR ratio & & & & .005 & .156 & .876 \\
\hline HR Experience & & & & .063 & 1.993 & .047 \\
\hline Human capital & & & & .024 & .779 & .436 \\
\hline Outsourcing & & & & .004 & .123 & .902 \\
\hline e-HRM sophistication & & & & .188 & 5.655 & .000 \\
\hline Adjusted R Square (model) & \multicolumn{3}{|c|}{.060} & \multicolumn{3}{|c|}{.106} \\
\hline F change & \multicolumn{3}{|c|}{30.561} & \multicolumn{3}{|c|}{7.860} \\
\hline Significance of $F$ change & \multicolumn{3}{|c|}{.000} & \multicolumn{3}{|c|}{.000} \\
\hline
\end{tabular}


Using e-HRM use as the criterion variable, both steps of the linear regression analysis produced a significant $\mathrm{F}$ change $(\mathrm{p}<0.01)$. The adjusted $\mathrm{R}$ squared value for the two steps was 0.106 .

An examination of the results in table 4 shows that, of the controls, organization size had a significant positive effect on e-HRM use, suggesting that larger organizations use eHRM for a wider range of uses. Of the predictors, strategic involvement of $H R$ had a significant positive effect on e-HRM use suggesting that e-HRM is used for a wider range of activities in firms where the HR function plays a more strategic role. HR experience also had a significant positive effect on HRIS use suggesting that firms use e-HRM for more activities when their HR manager has more experience. E-HRM sophistication was also significantly positively related to e-HRM use showing firms with a more sophisticated e-HRM use the system for more activities

\section{Discussion}

We have examined the relationship between a number of organizational characteristics and the breath of use and sophistication of e-HRM in order to examine the consequences of e-HRM and to provide some insight into the use of e-HRM to improve the value of the HR function through its contribution to the competitive advantage of the firm.

In relation to our controls, we found that organization size had a significant positive relationship with both use and sophistication of e-HRM. This is in support of prior research (Ball, 2001) and can be explained by the fact that e-HRM requires an initial investment that may be more accessible for large organisations. The efficiency savings produced by e-HRM may be greater in larger organisations due to the economies of scale caused by the larger numbers of people to be managed. We did not find a significant relationship between organization age and e-HRM use or sophistication. 
We formulated a number of hypotheses of the relationships between organizational characteristics and e-HRM within the framework of the resource-based view. We suggested that e-HRM may be a vehicle by which the HR function can reduce the costs (exchange value) associated with HRM and improve the service that they offer to the firm (use value) therefore producing a higher "consumer surplus" and thus contributing to the organisation's competitive advantage (Bowman and Ambrosini, 2000). In accordance with Bowman and Ambrosini's distinction between generic labour and differential labour we proposed that, if the HR function are seen as a resource themselves, they would aim to improve the cost efficiency of generic labour (transactional HR activities) and increase their focus on differential labour (strategic and value adding activities) in order to improve their value and contribution to competitive advantage.

Our first hypothesis, that organizations with a lower ratio of HR staff to total employees would be more likely to use e-HRM was not supported by the data for either eHRM use or sophistication. This is surprising as we would expect the use of e-HRM to replace HR practitioners in completing administrative HR activities. Indeed, past qualitative research has found that the introduction of e-HRM may result in a reduction in HR headcount (Parry and Tyson, 2006). This may indicate suggest that the use of e-HRM is not leading to the cost savings suggested by past literature in this area, at least not through a reduction in HR headcount. Of course, cost savings in other areas (such as reduced paper) may still be experienced. This may be due to a failure by organisations to implement e-HRM in such a manner that transactional tasks can be performed effectively without the need for human involvement. Alternatively, it could mean that, rather than being made redundant, HR staff in organizations with e-HRM are being re-deployed into other roles or onto other activities or that routine administration staff are being removed and replaced by staff in business partner roles. This could be technology related activities as suggested by Burbach and Dundon 
(2005) or it could mean that HR practitioners are being redeployed into roles that offer more value to the organisation or are more strategic. This suggestion is in line with the idea of removing unproductive labour and replacing it with differential labour (Bowman and Amrosini, 2000). This is an interesting and important finding that needs more investigation in order to provide an insight into the nature of the use of e-HRM in organisations.

Our second hypothesis, that organizations in which the HR function played a more strategic role would be more likely to use e-HRM, was supported for e-HRM use but not for e-HRM sophistication. This supports the literature that the use of e-HRM can facilitate the move to a more strategic role for the HR function (Marler, 2009; Martin et al, 2008; Ruel et al, 2004; Lepak and Snell, 1998; Shrivastiva and Shaw, 2004; Lawler and Mohrman, 2003) and also supports our suggestion above that the release of HR staff from administrative tasks may result in them being deployed onto other activities, in this case more strategic activities, rather than being made redundant. The fact that the e-HRM allows the HR function to focus on the delivery of the business strategy rather than transactional activities, therefore moving the emphasis of the function from generic labour to differential labour, means that it may increase its use value to the organisation and be able to provide a more significant contribution to the competitive advantage of the firm.

Hypothesis 3, that organisations in which the HR manager had more experience would be more likely to use HRM was supported for e-HRM use $(p<0.05)$ but not for e-HRM sophistication. This may be indicative of the fact that the HR Manager in organizations with wide use of e-HRM are performing more advanced, strategic tasks and therefore require a greater degree of knowledge and experience for their role, or it may reflect the fact that the introduction of e-HRM requires a certain degree of knowledge and experience in itself. 
We found a significant negative relationship between the devolution of HR tasks to line management and e-HRM sophistication (hypothesis 4). This relationship is in the opposite direction to that predicted. This suggests that organizations are using complex eHRM systems as an alternative to devolving HR tasks to line management, rather than as a means of facilitating this devolution. This is particularly surprising given that sophisticated e-HRM systems commonly include manager self-service systems that enable managers to perform HR tasks. The relationship between e-HRM use and devolution to line management was also negative but not significant. Further research is needed to examine this finding to establish which tasks, if any, are devolved to line management and the relationship of this to e-HRM use.

We found a highly significant positive relationship between HRO and e-HRM sophistication but not e-HRM use, therefore partly supporting our fifth hypothesis. It appears that organizations tend to use HRO and sophisticated e-HRM systems in conjunction with one another but that the extent of use of e-HRM across a range of HR activities is not related to outsourcing. This suggests that if the two innovations are related at all, they are used in a complimentary fashion rather than as an alternative for each other. We also found a significant positive relationship between e-HRM use and sophistication, suggesting that firms may develop the sophistication of their e-HRM system in order to use it across more HR activities.

Our final hypothesis, that organisations with a high level of qualified employees would be more likely to use e-HRM, was not supported. This may indicate that the existence of an effective HR function is important regardless of the nature of the workforce.

\section{Conclusions}


Our study has provided limited support for the assertion that the use of e-HRM may allow the HR function to increase its value (or the rents that it generates) through an increase in differential labour in the form of a strategic orientation. This supports past literature on the use of e-HRM (Marler, 2009; Martin et al, 2008; Ruel et al, 2004; Lepak and Snell, 1998) suggesting that the use of e-HRM can allow the HR function to increase its involvement in delivering strategy. However, our findings do not support the suggestion that e-HRM may allow HR to reduce headcount (and therefore costs) through the completion of transactional activities (generic labour) in a more efficient manner. This is perhaps the most interesting of our findings as e-HRM has past been commonly related to a reduction in number sof HR staff. This is not to say that transactional tasks are not being performed more efficiently there is a large body of literature that suggests that this is the case (Martin et al, 2008; Hendrickson, 2003; Ruel et al, 2004) - or that cost savings are not been achieved in other areas. It is more likely that HR practitioners are being redeployed into other activities. The relationship between e-HRM use and a strategic orientation suggests that these activities may be strategic (especially given that e-HRM is also associated with higher expertise in the HR manager), but it may be that HR staff are also being redeployed into shared-service centres or into technology support roles. More research of a qualitative nature is needed in order to establish investigate this. It may that the use of e-HRM allows the HR function to increase their use value without incurring additional costs (i.e. by employing additional staff) therefore increasing the overall value of the function and its contribution to the competitive advantage of the organisation through the more effective management, development and deployment of employees.

We have also demonstrated, through our use of the two measures of e-HRM use and sophistication, that the factors driving the use of e-HRM across a range of activities and the development of complex e-HRM systems are not necessarily the same. Although the two are 
related, in that the use of sophisticated systems may encourage an expansion of the use of such systems, e-HRM sophistication is related to lower HR devolution and the use of HRO, while breadth of e-HRM use is related to the strategic involvement of HR and the experience of the senior HR manager. This may suggest that the development of sophisticated e-HRM systems within organizations is related to the need to improve the quality and efficiency of the HR services to employees, while the breadth of e-HRM use is connected to a desire for the HR function to make use of its skills and adopt a more strategic role in the organization. This also requires further investigation.

Our study has a number of limitations. Firstly, we have used relatively simple measures of both e-HRM use and sophistication and of our predictors. While this allows us to conduct a useful investigation of relationships, it does not provide the depth or detail to fully explain these relationships Specifically, we have combined different uses of e-HRM into a single measure of e-HRM use, where in fact the use of e-HRM for sophisticated functions such as e-recruitment or e-learning may have a very different impact compared to those for purely administrative tasks such as payroll administration or absence recording. In a number of cases we have used simplistic measures as a proxy for more complex details such as using the experience of the most senior HR manager to represent the experience in the HR team, or the percentage of graduates to represent the level of qualified employees. While these measures are in line with prior research (e.g. Delmotte and Sels, 2008), it may be that they do not fully capture this information. We have presented only snapshot data so only establish a relationship between e-HRM use and other variables. Future longitudinal research is needed in order to investigate causality. We are also aware of the limitations of surveys using a single source of data. We attempted to overcome this limitation by asking that the survey be completed by the most senior HR practitioner in the organization and by ensuring that the questions required only factual and not subjective data. However, future research 
using multiple sources of data should be conducted. The reliability of the back translation of questionnaires was also not evaluated, although changes were made to the translations in order to ensure equivalence of different versions.

We have added to research on e-HRM conducted in single counties by providing an analysis across countries. However, for simplicity's sake, we have not examined national differences in these relationships. Recent research by Marler, Parry and Lepak (2009) has suggested that national context may an impact on the relationship between e-HRM use and the role of the HR function. Further research is needed to fully explore the impact of national context on the use and consequences of e-HRM use. Finally, we have not examined the relationship between e-HRM use and actual organisational performance as it would be difficult to isolate this link through survey research. However, future research should further examine this relationship.

Despite these limitations, this research has made an important contribution to the field of e-HRM research through a large, international study of the use of e-HRM within a sound theoretical framework. We have added to the work of authors such as Wright et al (2001) in using the RBV as a basis for an analysis of HRM. More specifically, within the framework of the RBV, we have provided an insight into the potential of e-HRM to improve the value of the HR function and also to improve its capability to contribute to the competitive advantage of the firm through improve efficiency, effectiveness and an increased role in delivering the business strategy. Organisations should consider the value of the HR function in the adoption of e-HRM and make the effort to design and implement the system in such a way so as to promote and maximise these benefits. 


\section{References}

Ball K. (2001). The use of human resource information systems: A survey. Personnel Review, 30 (6), 677-693.

Barney J. (1986). Strategic factor markets: Expectations, luck and business strategy. Management Science, 32, 1231-1241.

Barney J. (1991). Firm resources and sustained competitive advantage. Journal of Management, 17 (1), 99-120.

Bondarouk T. and Ruel H. (2009). Electronic human resource management: Challenges in the digital era. International Journal of Human Resource Management, 20 (3), 505 514.

Bowman C. and Ambrosini V. (2000). Value creation versus value capture: Towards a coherent definition of value in strategy. British Journal of Management, 11, 1-15.

Brewster, C., Hegewisch, A., Mayne, L. and Tregaskis, O. (1994), "Methodology of the Price Waterhouse Cranfield Project", in Brewster, C., Hegewisch, A. (Eds),Policy and Practice in European Human Resource Management, Routledge, London.

Buckley P., Minnette K., Joy D. and Michaelis J. (2004). The use of an automated employment recruiting and screening system for temporary professional employees: A case study. Human Resource Management, 43 (2/3), 233-241.

Burbach R. and Dundon T. (2005). The strategic potential of human resource information systems: Evidence from the Republic of Ireland. International Employment Relations Review, 11 (1/2), 97-117.

CedarCrestone (2007). The CedarCrestone 2007-2008 HR Systems Survey: HR Technologies, Service Delivery Approaches and Metrics. $10^{\text {th }}$ Annual Edition.

Chartered Institute of Personnel and Development (2005). People Management and technology: Progress and Potential. London: CIPD.

Cooke F., Shen J. and McBride A. (2005). Outsourcing HR as a competitive strategy? A literature review and an assessment of implications. Human Resource Management, $44(4), 413-432$. 
Conklin D. (2005). Risks and rewards in HR business process outsourcing. Long Range Planning, 38, 579-598.

Delmotte J. and Sels L. (2008). HR outsourcing: threat or opportunity? Personnel Review, 37 (5), 543-563.

Dierickx, I. and Cool, K. (1989). Asset Stock Accumulation and Sustainability of Competitive Advantage. Management Science, 35 (12), 1504-1511.

Eisenhardt K.M. and Martin J.A. (2000). Dynamic capabilities: What are they? Strategic Management Journal, 21 (10-11), 1105-1121.

Enshur E., Nielson T. and Grant-Vallone E. (2002). Effects of the internet and technology on HR processes. Organizational Dynamics, 31 (3), 224-244.

Florkowski G. And Olivias-Lujan M. (2006). The diffusion of human resource informationtechnology innovations in US and non-US firms. Personnel Review, 35 (6), 684-710.

Gardner, S., Lepak D. and Bartel K. (2003). Virtual HR: The impact of information technology on the human resource professional. Journal of Vocational Behavior, 63 (2), 159-179.

Hendrickson A. (2003). Human resource information systems: Backbone technology for contemporary human resources. Journal of Labor Research, 24 (3), 381-394.

Kanter R. (2003). "Foreward" in Effron M., Gandossy R. and Goldsmith M. (Eds). Human Resouces in the $21^{\text {st }}$ Century. Hobeken: John Wiley and Sons.

Kovach K. and Cathcart C. (1999). Human resource information systems (HRIS): Providing business with rapid data access, information exchange and strategic advantage. Public Personnel Management, 28 (2), 275-282.

Kumar, N., Stern, L.W., Anderson, J.C. (1993), "Conducting interorganizational research using key informants", Academy of Management Journal, Vol. 36 No.6, pp.1163-51.

Larsen H. and Brewster C. (2003). Line management responsibility for HRM: What is happening in Europe? Employee Relations, 25 (3), 228-44.

Lawler E. And Mohrman S. (2003). HR as a strategic partner: What does it take to make it happen? Human Resource Planning, 20 (2), 37-47. 
Lengnick-Hall M. and Moritz S. (2003). The impact of e-HR on the human resource management function. Journal of Labor Research, 24 (3) 365-379

Lepak D. and Snell S. (1998). Virtual, HR: Strategic human resource management in the $21^{\text {st }}$ century, Human Resource Management Review, 8 (3), 215-234.

Lockett A. (2005). Edith Penrose's legacy to the resource-based view. Managerial and Decision Economics, 26, 83-98.

Lockett A., Thompson S. and Morgenstern U. (2009). The development of the resourcebased view: A critical appraisal. International Journal of Management Reviews, 11 (1), 9-28.

Marler J. (2009). Making human resources strategic by going to the Net: reality or myth? International Journal of Human Resource Management, 20 (3), 515-527.

Marler J., Parry E. and Lepak D. (2009). E-HRM in different national contexts: Strategic trigger or strategic choice? Paper presented at the Academy of Management Annual Conference, August 2009, Chicago, USA.

Martin G., Redddington M. and Alexander H. (2008). Technology, Outsourcing and Transforming HR. Oxford, UK: Elsevier.

Martinsons, M G (1994), "Benchmarking Human Resource Information Systems in Canada and Hong Kong", Information \& Management.

Parry, E. and Tyson, S. The impact of technological systems on the HR role: does the use of technology enable the HR function to become a strategic business partner? First European Academic Workshop on eHRM, October, 2006, Twente, Netherlands.

Paauwe J. (2004). HRM and performance: Achieving long term viability. Oxford: Open University Press

Penrose E. T. (1959). The Theory of Growth of the Firm. Oxford, UK: Blackwell.

Peteraf M.A. (1993). The cornerstone of competitive advantage: The resource-based view. Strategic Management Journal, 14, 170-181.

Ruel H., Bondarouk T. and Van der Vald, (2006). The contribution of e-HRM to HRM effectiveness. Employee Relations, 29 (3), 280-291. 
Rumelt R.P. (1982). Diversification strategy and profitability, Strategic Management Journal, 3, 359-369.

Ruta C. (2005). The application of change management theory to HR portal implementation in subsidiaries of multinational corporations. Human Resource Management, 44 (1), $35-53$.

Shrivastiva S. and Shaw J. (2004). Liberating HR through technology. Human Resource Management, 42 (3), 201-222.

Snell S., Stueber D.and Lepak D. (2002). Virtual HR departments: getting out of the middle. In: R. Henneman and D. Greenberger (Eds.), Human Resource Management in Vitual Organizations, Greenwich: Information Age Publishing.

Stroehmeier S. (2009). Concepts of e-HRM consequences: a categorisation, review and suggestion. International Journal of Human Resource Management, 20 (3), 528-543.

Stroehmeier S. (2007). Research in e-HRM: Review and implications. Human Resource Management Review, 17, 19-37.

Tansley C., Newell S. and Williams H. (2001). Effecting HRM-style practices through an integrated human resource information system. Personnel Review, 30 (3), 351-370.

Teece, D. J., Pisano, G., \& Shuen, A. (1997). Dynamic capabilities and strategic management. Strategic Management Journal, 18 (7), 509-533.

Thite M. and Kavanagh M. (2009). Evolution of human resource management and human resource information systems: the role of information technology. In: M. Kavanagh and M. Thite, Human Resource Information Systems: Basics, Applications and Future Directions. Thousand Oaks: Sage.

Tremblay M., Patry M. And Lanoie P. (2008). Human resource outsourcing in Canadian organizations: An empirical analysis of the role of organizational characteristics, transaction costs and risks. International Journal of Human Resource Management, 19

Ulrich D. (1996). Human Resource Champions. Boston: Harvard Business Review.

Wernerfelt B. (1984). A resource-based view of the firm. Strategic Management Journal, 5, 171-180. 
Whittaker S. and Marchington M. (2003). Devolving HR responsibility to the line: Threat, opportunity or partnership? Employee Relations, 25 (3), 245-261.

Wright P., Dunford B. and Snell S. (2001). Contributions of resource-based view of the firm to the field of strategic HRM: Convergence of two fields. Journal of Management, 27, 701-721.

Wright, P.M., McMahon, G.C., McWilliams, A. (1994), "Human resources and sustained competitive advantage: a resource based perspective", International Journal of Human Resource Management, 5 (2), 301-26 